\title{
The Effect of Hypnosis on The Level of Anniversity of Women With HIV/AIDS
}

\author{
$\underline{\left.\text { Hesti Wiij Utami }{ }^{1}\right) \text { Wiwin Mintarsih'2) Nita Nurvita }}$ \\ Email : hestiwijiutami@gmail.com
}

\begin{abstract}
Background: The level of anxiety of women with HIV / AIDS has different categories for each individual, the main cause of this anxiety is hopelessness to depression due to the diagnosis obtained. A person's level of anxiety can be overcome by various methods, one of which is hypnosis. Hypnosis is a natural method used to relieve fear, panic, tension and mental stress. Hypnosis is carried out by direct contact with a person's subconscious mind, giving positive suggestions so that a person can build a positive emotional state. The purpose of this study was to determine the effect of hypnosis on the level of anxiety of women with HIV / AIDS in Tasikmalaya City in 2019.

Methods: This type of research is included in experimental research with a quantitative approach. The design of this research is Pre-Experimental Design with One Group Pretest-Posttest Design. The population was 19 people with the total sampling technique of 19 people. The data analysis technique used the Wilcoxon Test.

Results: The results of this study found that the anxiety level of women with HIV / AIDS before hypnosis was at a moderate level of anxiety. After hypnosis, most of the anxiety levels were in the mild category. The Wilcoxon test results, the value is less than a $(0.001<0.05)$, so it shows that there is an effect of hypnosis on the anxiety level of women with HIV / AIDS. The results of this study found that the anxiety level of women with HIV / AIDS before hypnosis was at a moderate level of anxiety. After hypnosis, most of the anxiety levels were in the mild category. The Wilcoxon test results, the value is less than a $(0.001<0.05)$, so it shows that there is an effect of hypnosis on the anxiety level of women with HIV / AIDS.

Conclusion: the anxiety level of women with HIV / AIDS before hypnosis was at a moderate level of anxiety. After hypnosis, most of the anxiety levels were in the mild category. The Wilcoxon test results, the value is less than a $(0.001<0.05)$, so it shows that there is an effect of hypnosis on the anxiety level of women with HIV / AIDS
\end{abstract}

Keyword : Anxiety level; women with HIV / AIDS; Hypnosis

1,2,3) Poltekkes Kemenkes Tasikmalaya, Indonesia (10 pt normal italic) Jalan Cilolohan No. 35 Kota Tasikmalaya Jawa Barat 46115, Indonesia

Background. Human Immunodeficiency Virus (HIV) is a virus that attacks cells of a person's immune system, causing damage to the immune system. The virus can infect the immune system which functions to fight germs in the human body. This results in decreased function of the immune system or often called Immunodeficiency (WHO). When a person's immune system is infected with HIV it can make a person's body more susceptible to various diseases. This is called Acquired Immunodeficiency Syndrome, a condition in which a person's body is infected with HIV which causes various viruses and bacteria to attack the body to become a syndrome (WHO, 2017).

In Indonesia HIV was first reported in April 1987 in Bali, this happens to people of Dutch nationality in Indonesia. Since the first case until now the spread of HIV cases has increased very rapidly. PAs of 2016 , Indonesia had 48,000 new HIV infections and 38,000 AIDS-related deaths. There were 620,000 people living with HIV in 2016, of whom $13 \%$ accessed antiretroviral therapy. Among pregnant women living with HIV, $14 \%$ access treatment or prophylaxis to prevent HIV transmission to their children. An estimated 3200 children have recently been infected with HIV because of mother-to-child transmission (UNAIDS, 2017).

According to data from the Health Office for the Prevention and Control of Disease in the City of Tasikmalaya, the number of people with HIV / AIDS (PLWHA) from 2007 - 2017 it reached 501 people. Two hundred and seventy 
people living with HIV are currently on ARV therapy, and 231 people living with HIV are not on ARV therapy due to various reasons, including moving domicile and passing away (P2P section of the Health Office, 2017). According to the Chairman of the Peer Support Group (KDS), 62 new cases of HIV / AIDS sufferers were found in the City of Tasikmalaya from January-September 2018 (Monday, 29/10/2018 at Asia Plaza Tasikmalaya). HIV / AIDS sufferers who experience mental health problems come from the High-Risk Couples risk group, where they contract HIV from their husbands who are the HRM group. Most people with HIV / AIDS who experience mental health problems do not play a direct role in the spread of HIV. There are two types of treatment for anxiety disorders experienced by PLWHA, namely Pharmacological and Non Pharmacological treatments. Pharmacological treatment is in the form of administering drugs according to a doctor's prescription, while nonpharmacological treatment includes Distraction, Progressive Relaxation, Meditation and Hypnosis (Republic of Indonesia Ministry of Health Report, 2017).

Hypnosis is a communication that aims to influence a person so that he changes his level of consciousness, a conscious state that occurs naturally in which a person is able to live up to certain thoughts and suggestions to achieve the desired psychological, physical and spiritual changes by lowering brain waves from beta to alpha, theta. and deltas. Hypnosis, which is directly connected to the level of consciousness and can impart suggestions, provides direct sensors to the pituitary to order body parts according to the suggestions given to each individual can help reduce levels of anxiety and anxiety disorders (Kuswandi et al., 2016). Previous research has been conducted by Iriyanto Adi, "The effect of Hypnotherapy on reducing anxiety in chemotherapy patients at Telogorejo Hospital" in 2004. The result was that Hypnosis reduced anxiety levels when undergoing chemotherapy $(p=0.000)$. The conclusion is that Hypnosis has an effect on reducing anxiety levels when undergoing chemotherapy.

After conducting a preliminary study in the Tasikmalaya City area, it was found that women with HIV / AIDS had never received intervention either pharmacologically or non pharmacologically. In a preliminary study to measure anxiety disorders using the HARS scale, results showed 4 out of 5 women with HIV / AIDS had severe anxiety. For 1 woman with HIV / AIDS has moderate anxiety.

Based on the results of these preliminary studies, the authors are interested in conducting research on non-pharmacological treatments that can help reduce anxiety levels in women with HIV / AIDS. The applicable title is "The Effect of Hypnosis on Anxiety Levels of Women with HIV / AIDS in the City of Tasikmalaya in 2019"

Methods. This type of research is included in experimental research with a quantitative approach. The design of this research is PreExperimental Design with the One Group Pretest-Posttest Design approach technique. The research was conducted from January to February in the City of Tasikmalaya and took place at the residence of each respondent. The number of PLWHA in Tasikmalaya City has 19 new cases during 2018.

The population of people living with HIV / AIDS (PLWHA) in Tasikmalaya City was found during 2018 as many as 19 people with a total sampling technique of 19 people.

The instrument to measure the level of anxiety in the sample used the HARS (Hamilton Anxiety Rating Scale) scale. The instrument for measuring the level of anxiety of women with HIV / AIDS was not tested for validity and reliability because it was a standard measuring tool.

The univariate analysis in the study looked at a picture of anxiety levels before and after being given hypnosis. The data analysis technique uses the Frequency Distribution. The bivariate analysis in this study analyzed the effect of hypnosis on the anxiety level of women with HIV / AIDS. This study is a One Group Pretest-PostTest Design with the Wilcoxon Test that has met the requirements.

\section{Result and Discussion.}

Table 1 Levels of Anxiety in Women with HIV / AIDS Before doing Hypnosis in the City of Tasikmalaya in 2019

\begin{tabular}{ccc}
\hline Category & Frequency $(\mathbf{N})$ & Percent (\%) \\
\hline Light & 5 & 26.3 \\
Moderate & 13 & 68.4 \\
Weight & 1 & 5.3 \\
\hline Total & 19 & 100 \\
\hline
\end{tabular}

Based on table 1, it is known that the level of anxiety before hypnosis is performed has the largest percentage, namely the level of anxiety 
in the moderate category, there are 13 people $(68.4 \%)$.

Table 2. Levels of Anxiety in Women with HIV / AIDS Before doing Hypnosis in the City of Tasikmalaya in 2019

\begin{tabular}{ccc}
\hline Category & Frequency $(\mathbf{N})$ & Percent $(\%)$ \\
\hline $\begin{array}{c}\text { No worries } \\
\text { Light }\end{array}$ & 2 & 10.5 \\
& 12 & 63.2 \\
Moderate & 5 & 26.3 \\
\hline Total & 19 & 100 \\
\hline
\end{tabular}

Based on table 2, it is known that the level of anxiety in women with HIV / AIDS after hypnosis was carried out in Tasikmalaya City in 2019 , the largest percentage had an anxiety level in the mild category, namely 12 people (63.2\%).

To determine the effect of hypnosis on the level of anxiety in women with HIV / AIDS in the City of Tasikmalaya in 2019, a hypothesis was tested, with the proposed hypothesis that "There is an effect of hypnosis on anxiety levels in women with HIV / AIDS. The test results can be seen in the following table

Table 3 The Effect of Hypnosis on Anxiety Levels in Women with HIV / AIDS in Tasikmalaya City in 2019

\begin{tabular}{lcc}
\hline \multicolumn{1}{c}{ Variable } & Z & p value \\
& & \\
\hline $\begin{array}{l}\text { The Effect of Hypnosis } \\
\text { on Anxiety Levels in }\end{array}$ & $-3,207$ & 0.001 \\
Women with HIV / AIDS & & \\
\hline
\end{tabular}

In table 3, the results of statistical tests using the Wilcoxon test are obtained with a value of 0.001 . This value is less than 0.05 , so this indicates that there is a decrease in anxiety levels in women with HIV / AIDS before and after being given hypnosis. With this it can be concluded that the hypothesis proposed "There is an Effect of Hypnosis on the Anxiety Level of Women with HIV / AIDS can be accepted.

Based on the results of research that has been conducted regarding the level of anxiety of women with HIV / AIDS in the City of Tasikmalaya in 2019 before hypnosis, it was found that most respondents had a moderate level of anxiety as many as 13 people (68.4\%).

With the results of this study, it can be seen that women with HIV / AIDS in Tasikmalaya City have different levels of anxiety disorders.
From the results of interviews with HIV / AIDS women, as many as 19 people felt almost hopeless because they were worried that they could transmit their illness to their families and were tired of discrimination by the surrounding community.

This is reinforced by the theory according to Sunaryo (2013) that discouragement can occur when facing changes in the life cycle, social and historical conditions, as well as the transience of life in the presence of eternal life (death). As a result, a person sometimes experiences feelings about their life as meaningless. The pain that arises results in emotional disturbances related to neurosis, namely emotional adjustment errors due to unconscious conflicts that cannot be resolved properly.

In addition, according to WHO (2017) women with HIV / AIDS has an infected immune system so that it cannot fight germs that attack the human body, then the body is easily attacked by diseases that complicate women.

This is in accordance with the theory according to Page in Manurung (2016) that causes anxiety level disorders, one of which is the physical factor where physical weakness can weaken an individual's mental state, making it easier for anxiety to arise. Difficulty moving, unable to carry out activities as usual can lead to low self-concept.

This is in accordance with the explanation from Stuart in YS Budi (2017) regarding the factors that affect individual anxiety, one of which is biological theory. Physical disturbances and decreased individual ability to cope with stressors are a companion to anxiety, as evidenced by the fact that the brain contains special receptors that can increase neuroregulatory inhibition (GABA) which plays a role in mechanisms related to anxiety.

The anxiety of the woman with HIV / AIDS is part of a logical function that weakens intuition or vice versa. Anxiety occurs as a result of an individual's maladaptive response in the form of destructive coping. A failed stressor adjustment or normalization has resulted in tension and increased focus on issues that are deemed important. Excessive focus without control will override constructive coping so that individuals experience selective attention which is relatively misleading (lost). Within the range of adaptive responses to anxiety, individuals are required to modify cognitive and affective 
intelligence to form more accelerated constructive coping with varied accepting abilities.

Based on the results of research that has been conducted regarding the level of anxiety of women with HIV / AIDS in Tasikmalaya City after hypnosis, it was found that most respondents had a level of anxiety in the mild category as many as 12 people (63.2\%). Thus, women with HIV / AIDS in Tasikmalaya City in 2019 after being given hypnosis treatment can relieve the anxiety they face, by thinking about positive things and being able to control their thoughts so that they always have a positive attitude towards themselves and the environment, successfully reducing anxiety in living their daily lives as a woman. with HIV / AIDS.

This is in line with research by $L u$ and $L u$ (2013) which states that hypnosis therapy can reduce patient anxiety levels and increase patient calm. Two groups of students having high scores on the anxiety test questionnaire were treated by desensitization under hypnosis or desensitization after relaxation training with biofeedback. Both groups showed a significant reduction of test anxiety after treatment when compared to the non-contact control group ( $p>$ $0.05)$. From this study it was concluded that there was an effect of hypnotherapy on anxiety levels. In the intervention group, when the post test was carried out, PLWHA had a decreased level of anxiety (Spies G, 2011).

In a study conducted by Linda Anggraeni (2018) entitled "The Effect of Hypnosis on Anxiety Levels of Third Trimester Primigravida Pregnant Women in Facing Childbirth" with a sample size of 38 people, the results obtained pvalues less than $\alpha(0.000<0.05)$. With these results, the hypothesis is accepted so that Hypnosis does have an effect on reducing the anxiety level of third trimester primigravida pregnant women in facing childbirth.

Based on the two studies above, it is found in accordance with the theory of Laura King (2010) that one of the management of anxiety can be done with relaxation therapy in the form of relaxation, meditation, relaxation of imagination and visualization and progressive relaxation.

Based on the results of research that has been conducted regarding the effect of hypnosis on the level of anxiety of women with HIV / AIDS in the City of Tasikmalaya in 2019, the results obtained from a statistical test with a Wilcoxon ( $Z$ ) test value of -3.207 with an pvalue of 0.001 . This shows pvalue less than $\alpha$ (0.05), thus there is an effect of hypnosis on the anxiety level of women with HIV / AIDS.

This is in accordance with the research conducted by Adi (2004) entitled "The effect of Hypnotherapy on reducing anxiety in chemotherapy patients at Telogorejo Hospital" and the results showed that hypnosis can reduce the anxiety level of chemotherapy patients. The results of these studies are in accordance with the understanding and benefits of hypnosis itself.

According to Kuswandi, et al. (2016) hypnosis is a communication that aims to influence a person so that he changes his level of consciousness, a conscious state that occurs naturally in which a person is able to experience certain thoughts and suggestions to achieve the desired psychological, physical and spiritual changes by reducing waves. the brain from beta to alpha, theta and delta.

The existence of thoughts such as Humman Immunodeficiency Virus / Acquired Immunodeficiency Syndrome (HIV / AIDS) can accelerate death and lead to feelings of hopelessness accompanied by worries about spreading the virus to family or loved ones. This causes an increase in the work of the sympathetic nervous system making the endocrine system consisting of glands such as the adrenal, thyroid, and pituitary (gland control centers) release their respective hormones into the bloodstream in order to prepare the body for emergency situations. As a result, the autonomic nervous system activates the adrenal glands which affect the system of the hormones epinephrine and norepinephrine, causing dysregulation of the body's biochemistry, resulting in physical tension in women with Humman Immunodeficiency Virus I Acquired Immunodeficiency Syndrome (Dariyo, 1997 in Aprilia, 2010).

Hypnosis is carried out in accordance with the steps and stages that have been determined to give results in accordance with the needs of the client. Each predetermined step can make success in the process or mechanism for achieving positive suggestions so that it can achieve the main goal, namely reducing anxiety levels.

In this study, each respondent was given the same intervention in accordance with the hypnosis guidelines used in order to obtain a decrease in anxiety levels for all respondents. 
Hypnosis also prioritizes instilling positive suggestions and giving happy thoughts so that it is expected to reduce one's anxiety level

The positive suggestions given during hypnosis will increase the production of the hormone serotonin in the body. The serotonin hormone itself is a hormone found in serotonergic neurons (central nervous system) and in enterochromafin cells (digestive tract) which functions to provide comfort and pleasure to each individual. There are many ways to produce the hormone serotonin apart from instilling positive suggestions, including getting sun exposure, exercise, massage to meditation (APA, 2013)

Conclusion and Suggestions. The anxiety level of women with Humman Immunodeficiency Virus / Acquired Immunodeficiency Syndrome before hypnosis was mostly in the moderate anxiety level category. The level of anxiety of women with Humman Immunodeficiency Virus / Acquired Immunodeficiency Syndrome after hypnosis, most of them are in the category of mild anxiety level. There is an effect of hypnosis on the anxiety level of women with Humman Immunodeficiency Virus / Acquired Immunodeficiency Syndrome

For Women with Humman Immunodeficiency Virus / Acquired Immunodeficiency Syndrome Instill positive suggestions in yourself and always think about positive things so as to reduce the risk of anxiety that may occur. For further researchers. It is hoped that the results of this study can be used as initial data for research in the same scope in the future.

Acknowledgements. Thanks to the researchers say to all those who have helped in completing this research.

\section{References}

American Psycriatic Association. (2013). Diagnostic and Statistical Manual of Mental Disorders, Fifth Edition. American Psycriatic Publishing. United State of America.

Anggraeni Linda. (2018). Pengaruh Hipnosis terhadap Tingkat Kecemasan Ibu Hamil Primigravida Trimester III dalam Menghadapi Persalinan, tersedia dalam; http://ejurnal.stikesbth.ac.id/index.php/P 3 M JKBTH/article/viewFile/404/362; diakses tanggal 22 November 2018
Aprilia. (2010). Hipnostetri: Rileks, nyaman danaman saat hamil daan melahirkan. Gagass Media. Jakarta

Arikunto, Suharsimi. (2013). Prosedur Penelitian Suatu Pendekatan Praktik, edisi revisi v, cetakan 12. Rineka Cipta. Jakarta

Djohan. (2010). Psikologi Musik, cetakan kedua. Penerbit Buku. Yogyakarta

King, Laura A. (2010). Psikologi Umum. Salemba Humanika. Jakarta.

Kuswandi, Lanny. (2016). Modul Panduan Pelatihan Basic Hypnosis dan Hypnobirthing. Hypno-birthing Indonesia. Jakarta

Laksana, Hari. (2017). Hypnotic Power Rahasia membaca dan Mempengaruhi Isi Hati dan Pikiran Orang Lain dengan Hipnotis, Araska, Yogjakarta

Laporan Kementerian Kesehatan RI. (2017). AIDS Kementerian Kesehatan. Diperoleh tanggal 30 Oktober 2018, dari http://siha.depkes.go.id/portal/files uplo ad/Laporan HIV AIDS TW 12017 re v.pdf

Liangan, Raaymo. (2013). HARS Penilaian Kecemasan, tersedia dalam: httpss://www.scribd.com; diakses tanggal 16 Oktober 2018

Mandal. (2008). Penyakit Infeksi, Erlangga Medical Series, Jakarta

Manurung, Nixson. (2016). Terapi Raminiscence, CV. Trans Info Mediaa. Jakarta Timur

Nazir, Moh. (2011). Metode Penelitian. Penerbit Ghalia Indonesia. Bogor

Nursalam. (2013). Metodologi Penelitian IImu Keperawatan. Salemba Medika. Jakarta

Prawirohardjo, Sarwono. (2008). IImu Kebidanan. PT Bina Pustaka Sarwono Prawirohardjo. Jakarta

Priyanto, Duwi. (2012). Cara Kilat Belajar Analisis Data SPSS 20. ANDI. Yogjakarta

Rana, R. (2010). The Relationship between Test Anxiety and Academic Achievment. Bulletin of Education and Research December 2010, 32;2 p. 63-74

Riyanto, Adi. (2011). Metodologi Penelitian Kesehatan. Nuha Medika. Yogjakarta

Sugiarti. (2009). Pengaruh Kepercayaan Diri dan Dukugan Keluarga Terhadap Kecemasan Menghadapi Menopouse Pada Ibu Rumah Tangga. Jurnal Sultan 
Agung, Juni-Agustus, XXXVIII(112); 4553.

Sugiyono. (2013). Metodelogi Penelitian Kuantitatif, Kualitatif Dan R\&D, ALFABETA. Bandung

Tim Naskah Dapur Sedunia. (2011). Penyakit AIDS. Amalia Book. Bandung

Trihendradi. (2012). Step by Step SPSS Analisis Data Statistik. ANDI. Yogjakarta

Triyani. (2016). Pengaruh Hipnosis terhadap Tingkat Kecemasan lbu Hamil Nullipara Triwulan III dalam Persiapan Menghadapi Persalinan, The Southeast
Asian Journal of Midwifery, Vol 2/1, Hal 24-32.

UNAIDS. (2017). Indonesia, Diperoleh 28 Oktober 2018, dari http://www.unaids.org/en/regionscountri es/countries/indonesia

WHO. (2017). HIV/AIDS, Diperoleh 28 Oktober 2018, dari http://www.who.int/hiv/en/

YS Budi. (2017). Faktor - faktor yang mempengaruhi Kecemasan, tersedia dalam https://repostory.umy.ac.id; diakses tanggal 10 Oktober 2018 